Narrative Works

Issues, Investigations, \& Interventions

\title{
Individuality and Continuity in Narrating across Generations
}

\section{Vieda Skultans}

Volume 10, 2020

Special Issue: Amor Narratio: A Festschrift For Catherine Kohler Riessman

URI: https://id.erudit.org/iderudit/1076917ar

DOI: https://doi.org/10.7202/1076917ar

See table of contents

Publisher(s)

Centre for Interdisciplinary Research on Narrative, St. Thomas University

ISSN

1925-0622 (digital)

Explore this journal

Cite this article

Skultans, V. (2020). Individuality and Continuity in Narrating across

Generations. Narrative Works, 10, 50-59. https://doi.org/10.7202/1076917ar
Article abstract

This article explores the commonalities of structure in the life histories of a mother and her daughter. I argue that sharing the same story does not preclude the existence of a strong and distinctive sense of self. Agency and selfhood are intimately connected with interpretation and the pursuit of understanding. In order to illuminate this relationship, I draw upon ideas of musical form and interpretation that suggest how this might come about.
This document is protected by copyright law. Use of the services of Érudit (including reproduction) is subject to its terms and conditions, which can be viewed online.

https://apropos.erudit.org/en/users/policy-on-use/ 


\title{
NARRATIVE WORKS \\ Issues, Investigations, \& Interventions
}

\author{
SPECIAL ISSUE
}

AMOR NARRATIO: A FESTSCHRIFT FOR

CATHERINE KOHLER RIESSMAN

\section{Individuality and Continuity in Narrating across Generations}

\author{
Vieda Skultans \\ University of Latvia \& University of Bristol
}

\begin{abstract}
This article explores the commonalities of structure in the life histories of a mother and her daughter. I argue that sharing the same story does not preclude the existence of a strong and distinctive sense of self. Agency and selfhood are intimately connected with interpretation and the pursuit of understanding. In order to illuminate this relationship, I draw upon ideas of musical form and interpretation that suggest how this might come about.
\end{abstract}

Keywords:

Music, narratives, generations, life histories

As in the art of music, creation and interpretation are closely linked. I want to suggest that authoring and interpretation are as indissolubly linked in the verbal arts of life story telling. Although the author of the original life has died, the story lives on. It demands a hearing. The dimension of generation allows the first storyteller to choose the beginning of the story, but while its rereadings continue, its ending is indefinitely deferred.

My article has come about through the death of one of my most cherished informants, Milda. In the summer of 1999, I returned to the parish of Drusti in order to continue, so I thought, with Milda's story. I learned that she had died in the spring of that year. My dismay over the death concerned not only the loss of a person, but also the abrupt termination of a story, for it seemed that the story was now to be frozen after the storyteller had died; an unexpected closure had been bestowed upon it. However, while asking after the whereabouts of Milda, I 
encountered her 60-year-old daughter, Mudra. In the course of our growing friendship and conversations, Mudra's own life story began to emerge. I was unprepared for the resurrection of the mother's literary and emotional world through the process of the daughter's storytelling. Just as there is an elusive but very real relationship between a work of art and what Williams (1979) calls the structure of feeling of a period, so too there is a relationship between enduring structures of meaning and life stories (p.159). However, despite the continuity of structures, mother and daughter conveyed quite distinctive senses of self. The problematic which I, therefore, address is how continuity of structure can be reconciled with a powerful sense of self.

\section{Theoretical Background}

My theoretical approach could not have developed without the implicit and explicit support of Cathy Riessman's work. During the early part of my career, an interest in life stories spelt academic suicide. Life history work was for those who lacked theoretical acumen. The publication of Narrative Theory in 1991 changed all that and gave us courage. Without Cathy, I would not have been brave enough to search for musical analogies.

Family histories raise questions of authorship and voice. Barthes (1977) famously wrote: "The birth of the reader must be at the cost of the death of the author" (p. 148). In the context of understanding family histories, Barthes' claim has a curious twist. The plots of transgenerational stories may share the same grammar, the same events may be re-enacted twice, and yet through performance, the stories leave room for the emergence of a distinctive self. I suggest that although stories survive as ongoing structures, they leave scope for interpretation and virtuosity of performance. Just "as a speaker can mean different things by the same linguistic sequence on different occasions," so too the same story can be re-enacted in different ways (Culler, 1982, p.110).

Thus, a sense of oneself does not depend upon a rupture with the past and its ways of speaking; it does not depend upon finding an entirely new language. Rather, it depends upon feeling at ease with an inherited vocabulary: it depends more upon continuity than upon discontinuity. I would rather argue that inherited languages, like old clothes, may be comforting and reassuring. They connect us to the past and the experience of others. 
Musical analogies suggest that life stories are not simply the unfolding of lives over time and a corresponding chronological development of narrative over time, but the elaboration of variations on a theme. Said's (1992) writing on musical elaboration has implications for autobiographical elaboration across generations: "Music is another way of telling ... built up through a whole series of affirmations and associations that come with not getting through time but of being in time (p. 100). Melody involves "mastering time according to a linear model, working through the material strictly. Looked at non-narratively, however, music is not just statement but statement and infinitely possible variations" (p.101) Auto/biographical elaboration, like musical elaboration, is about the affirmation and reaffirmation of repetition (p. 102). So auto/biographical narratives are structured both along a vertical and a horizontal axis with the horizontal axis representing sequences of change and the vertical axis representing enduring structures and meanings.

Mishler (1984) draws a similar musical analogy in the context of discussing problems of transcribing medical interviews: "Translating a score into music, a task similar to that of interpreting speech from a transcript, requires a competent performer, or mastery of the medium that permits "filling in" gaps in the score in order to "make' music" (p. 34). Thus, the concept of a structure to life is akin to the idea of musical form. Both encompass paradoxical meanings of underlying similarity and uniqueness.

The events in this story move between the cherished safety of the farmstead and dangerous forests and wilderness. Farm and forest represent the polarities of family intimacy, provision, and concern versus the unknown, the unpredictable, and the dangerous. Women are located in the farmstead and men in the forest. There is a memory of abundance and plenty and of ensuing famine; of human love and warmth and of coldness and treachery. The stepmother/other woman seeks to annihilate the main actors. Help comes from strangers. The story records women being forcefully removed from men and men making themselves unavailable to women. The actors are upheld, and the story moves forward by the power of God. Both mother and daughter contribute variations on each of these themes.

\section{Two Lives}

Milda first told me her life story in the summer of 1993. She was born in 1914, in the pagasts of Drusti in the province of Vidzeme, in 
Latvia. Her father was a farm labourer who benefited from the land reforms which were instituted between 1920 and 1924, which restricted the size of Baltic German manorial holdings and redistributed this land to landless farm labourers. In 1923, her father was allocated farmland, and the family - including 9-year-old Milda and her sister and four brothersall helped to build the farmstead, "Dukuli,," with their own hands. On her marriage, Milda moved to her husband's farmstead, "Smiltnieki." Thus, when war broke out, Milda was already a married woman. After the German occupation of Latvia in 1941, her husband had been drafted into the Latvian legion of the German army. He deserted. However, with the second occupation of Latvia by the Soviets in the autumn of 1945, her husband's mobilization by the Germans was held against him despite his having deserted. He was arrested and sent to work in the coalmines in Tula. The farmstead was on the boundary of the parish of Drusti and surrounded by forests. Milda's four brothers formed part of the widespread resistance movement to the Soviet occupation and went into hiding in the dense forests. They came to the farmstead for food and clothing and Milda was arrested and sentenced on the grounds of supporting forest partisans. Thus, in the aftermath of the war, Milda found herself effectively widowed with three young children aged 2, 4, and 6 . Milda was summoned to the war office in Cesis and was herself arrested. Her eldest daughter, Mudra, was 6 at the time of her arrest. Milda was sentenced to 4 years in a prison labour camp in Komsomolsk, according to the 12th section of the 58th clause, for supporting her brothers and failing to inform on them. Having served her sentence, Milda returned to Drusti to find that her husband, now returned, had taken a common-law wife in the family home. Her husband eventually returned to Milda and sought her forgiveness. However, the restitution of the marriage aroused the ire of the other woman, who burnt the marriage home in revenge. These, then, are the markers on the horizontal axis of Milda's life.

Movement in Mudra's life has been on a smaller scale. Mudra's earliest memories are of plenty, particularly where food was concerned. After her mother's disappearance, Mudra experienced hunger and had to do gruelling farm work. Mudra's father, having returned from the Tula coalmines, brought a substitute woman into the house. Mudra and her brothers and sister were an irritation to the new stepmother who, faithful to stereotype, had no love for them. 


\section{The Life Narratives}

Both mother and daughter recall a period of plenty. Milda even encounters plenty in the prison camp where she is put in charge of growing greenhouse vegetables:

There was the so-called parniki brigade (Russian for "greenhouse") where all the cucumbers and tomatoes were grown. Paradise was there. We could fulfil two or three plans and there were still some left over to eat. Even melons grew there. It was close to the border with Japan.

Mudra, too, remembers a time of plenty. She recalls her infancy when barns and granaries were crammed full, when the orchards yielded fruit and the bees honey: "Well there was everything in the house. The house was full. But when father returned there was nothing. There was an empty house."

In both stories, plenty is paired with famine. Our joint reading of the KGB file on her mother and the inventory of farmhouse belongings and products prompts Mudra to juxtapose the inventoried mountains of grain with her childish anxiety, lest her school mates should see the raw grain in her feces and infer the famine diet on which she subsisted. The polarized structure of the story has been handed down. The poetic use to which it is put emerges in the performance. The polarities of forest/men and farmstead/women underpin the stories of both women. When Milda was arrested in Cesis and interrogated, her self-defence recalled verbatim puts the polarities of farm/women and forest/men to rhetorical use in order to plead her innocence:

He said he'd seen a woman with two children in that house in the woods, but I had three. They put the house plan in front of me. I said I didn't understand anything of house plans. I've only been to school for three winters. I have a house in the woods, but I have three children and I don't recognize that man.

The three children, including her daughter Mudra, were left in the "house in the woods." Their father was first to return, from the coalmines in Tula. Mudra's memories of that early period are connected with the dangers of the forest. Her recollections are an elaboration on the forest theme initiated by her mother: 
This huge fat fellow jumped in front of me. He shut my mouth and twisted my head round. And I had a sense that my father was coming through the shaking undergrowth. And it seems he'd realized what was going on, what was happening in the forest.

On her return from Siberia, Milda was denied access to her children, since she was branded a criminal, and had to watch her children being neglected from afar: "I couldn't have any peace of mind. The teacher told me that the children were coming to school not having done their homework, absent minded and sleeping during lessons." "Father couldn't get up from the bed," and the children were left to gnaw raw potatoes. The absence of men leads to inappropriate expectations and work for both mother and daughter:

Here was forest work for my mother too. She returned from prison and she had to do all that mad forest work. That was the most terrible part.... My mother always believed in God. She said, "He is standing by me, he is helping me." She had such strength that she only complained of her head - she got such terrible headaches. But she said "Only work and work." And it's the same with me. I too need work, just work. I need to run and move and no matter that I could be at peace now.

But for both mother and daughter, work pushed them beyond the limits of their strength. During that same period of her mother's imprisonment, Mudra too was put to work:

What a mad time that was! We were little children and father put us to work, just to prove that we were conscientious workers. I was a little girl and my hands hurt. How old could I have been? I was in the sixth class when I had to go and help father with the lorry during the winter holiday and hand him frozen oats. I was a child and I had to lift frozen oats covered in snow.

These life events are experienced as inscriptions on the bodies of mother and daughter. Milda speaks of her head being so knocked about that she cannot remember anything. She also describes "a nerve deadness," a kind of paralysis which made movement impossible: 
I fell down as if dead with nerve deadness. I'm surprised I'm alive today. God leads me. If God didn't lead me, I wouldn't be alive today. I couldn't move a single joint, I couldn't lift my arm, or move a finger. I thought I wouldn't see my children again.

A similar paralysis was to affect her daughter. Mudra dates the onset of ill health from the period of lifting the frozen haystacks, which is why "doctors said it couldn't be treated." She describes early events as being "almost entombed in the bones for eternity." When she learned of the destruction of the farmstead by fire, she could control her mind but not her body:

I just told myself, "Don't think about it, everything is fine, everything is fine." I had to go to work and suddenly in a moment you fall to the ground from pain and can't move. Well it's a terrible state, simply terrible. I suffered for a long time and then I started taking all those nerve tablets, they were very strong .... Well it seems that, I can't quite figure it out, but it seems it's all inscribed (Latvian: ierakstīts) somewhere.

The power that underpins both lives and the narrative derive from God. Milda represents her hazardous journey home from the prison camp as guided by the hand of God. Her account is rich with biblical resonance:

It was exactly 1950. The ticket was free. I had some money too. We spoke Latvian, being all Latvians together. I couldn't speak Russian. Now the camp gates are open and I'm shown "Go there." ... And then I thought, "Dear God, give me some companion who would take me to Moscow, to Riga." And that time we were travelling forty days and nights to Komsomolsk and we got back to Moscow in twelve days. They brought me back to Moscow and showed me the Moscow Riga train. God has listened to all my prayers.

Just as Milda's journey back from the Gulag is sustained and speeded along by God, so too Mudra receives miraculous help to cycle uphill, though she describes her legs as being all but paralyzed:

Well I was given such strength that I practically flew up this enormous, steep hill even with my damaged legs. I didn't get 
down once. There's that sharp steep turning by the church and I rode up it yesterday. The bicycle seemed to be carrying me, it seemed that someone was carrying me. Our heavenly father has been standing by me.

\section{Reflections on the Life Stories}

These family narratives raise questions about the nature of selfhood. One of the principal ways in which selfhood is defined is through agency, but this raises further questions of what is meant by "agency." Sokefeld (1999) invokes "the ability to act on one's own account" and refers to Hannah Arendt's idea that agents are those able to seize the initiative or to make a beginning (p. 424). In this sense, it is clear that neither Milda nor her daughter Mudra qualify as agents. The ability to act on her own account, to take initiative, was removed from Milda. Her daughter Mudra arrived late, as we all do, upon a story already in progress. Our beginnings always incorporate other peoples' endings. And yet both are agents and assert their selfhood in a more profound way. Agency and selfhood reside in the interpretative search for meaning: in the interplay between temporal experience and narrative structures.

The composer Copland (1952) claimed that "In the art of music, creation and interpretation are indissolubly linked, more so than in any of the other arts, with the possible exception of dancing" (p. 40). I want to suggest that authoring and interpretation are as indissolubly linked in the verbal arts of life story telling. Although the author of the original life has died, the story lives on. It demands a hearing. As Gadamer (1989) reminds us, we can look away, but we cannot "hear away" (p. 462). But Milda, like a hermeneutical text (p. 387), can now only speak through the interpreter, in this case her daughter.

\section{Discussion}

Someone once said that history does not repeat itself, but historians do. Something of the same applies to lives and life histories. In the narrative accounts of mother and daughter, we find the same events re-enacted twice in quite different circumstances. There are dangerous encounters between men and women in the forest. There is the destruction or depletion of the farmstead. Work is exacted from women and children that is more appropriate to men and which maims their bodies. Help is given by strangers. Journeys and suffering are supported and speeded by 
God. The nature of the narrative encounters which make up these separate life stories are the same. The meanings that cluster around these auto/biographical events, their interpretation, if you like, belong to the same semantic domain and draw upon a series of polarities. Both lives record changes wrought by the treachery and evil of mankind and womankind and survival through divine sustenance.

A collective sense of self can be passed from mother and daughter to create an autobiographical narrative that belongs to a common emotional and conceptual habitat. A particular poetic construction of the world is passed from one generation to another and yet leaves room for a powerful statement of personal presence. The relationship of composer to performer provides an analogy that can illuminate the relationship between narrative structure and narrative performance.

I have tried to reconcile structuralism with performance theory and have drawn upon theories of musical interpretation in order to illuminate the relationship. Narrative permanence and change are but one example of the necessary interconnection between structure and subjectivity. They are to borrow the example used to illustrate the mind/ body relationship like to the two sides of a sheet of paper.

Bauman and Briggs (1990) argue that anthropologists have put so much emphasis on contextualizing storytelling precisely because stories are so readily detachable from their context. They ask: "What factors loosen the ties between performed discourse and its context?" (p. 73). Certainly, we can see in the case of this story of Milda and her daughter Mudra that the greater part of this story is jointly shared and, therefore, detachable. And yet in the tradition of the best virtuoso musical performers, Mudra succeeds in creating the illusion that author and performer are one and the same. Just as writers succeed in achieving priority over their predecessors-"For all of them achieve a style that captures and oddly retains priority over their precursors, so that the tyranny of time almost is overturned, and one can believe, for startled moments that they are being imitated by their ancestors" (Bloom, 1973, p. 141) — so too the enduring forms of her mother's story are reanimated and become so completely her own that we might be forgiven for thinking that the mother's story imitates her own.

So-who speaks in autobiographical narratives is no longer entirely clear. Although common-sense understandings suggest that the autobiographical voice traces back to a more or less stable knowing and feeling centre, attending to narrative structures suggests that vocal boundaries are blurred. Language both "speaks us" and we speak it. 
(Gadamer, 1989, p. 463). Within this performative space, the narrator reworks her own experience by feeding it to the plot structures of inherited stories.

Just as the processes of creation and interpretation are indissolubly linked in music, so too there is a close link between authorship and interpretation in the art of life story telling. Even if the original author has died, the story lives on and demands a hearing. Each narrator selects a beginning, but the ending is indefinitely deferred while the story is retold afresh.

\section{References}

Barthes, R. (1977). Image-music-text. (S. Heath, Trans.).Hill and Wang.

Bauman, R., \& Briggs, C. (1990). Poetics and performance as critical perspectives on language and social life. American Review of Anthropology, 19, 59-88.

Bloom, H. (1973). The anxiety of influence: A theory of poetry. Oxford University Press. Copland, A. (1952). Music and imagination. Oxford University Press.

Culler J. (1982). On deconstruction: Theory and criticism after structuralism. Cornell University Press.

Gadamer, H.-G.(1989). Truth and method ( $2^{\text {nd }}$ Ed.). Sheed and Ward.

Mishler, E. G. (1984). The discourse of medicine: Dialectics of medical interviews. Ablex.

Riessman, C. K. (1991). Narrative analysis. Sage.

Said, E. W. (1992). Musical elaborations. Vintage.

Sokefeld, M. (1999). Debating self, identity, and culture in anthropology. Current Anthropology, 40(4), 417-447.

Williams, R. (1979). Politics and letters: Interviews with New Left Review. New Left Books.

Vieda Skultans, PhD, has been lead researcher in the faculty of Sociology and Philosophy at the University of Latvia since 2013. She is also Professor Emerita of Social Anthropology at the University of Bristol, UK. She has conducted fieldwork in South Wales, India, and Latvia. Her publications include The Testimony of Lives: Narrative and Memory in Post-Soviet Latvia (Routledge, 1998). 